\title{
PERENCANAAN DAN PENGANGGARAN GREEN CAMPUS UNIVERSITAS DIPONEGORO
}

\author{
Irma Dewi Hapsari ${ }^{*}$, Nugroho Sumarjiyanto BM, Evi Yulia Purwanti \\ Magister Ilmu Ekonomi dan Studi Pembangunan, Fakultas Ekonomi, Universitas Diponegoro, Jl. Erlangga Tengah \\ No.17, Kampus Undip Pleburan, Semarang, Indonesia
}

\begin{abstract}
Abstrak
Green campus adalah sistem pendidikan, penelitian, dan pengabdian masyarakat yang ramah lingkungan serta melibatkan warga kampus dalam aktifitas lingkungan yang dapat memberikan manfaat positif bagi lingkungan, ekonomi, dan sosial. Tujuan penelitian ini adalah: (1) Menganalisis penerapan green campus di Undip berdasarkan tiga dimensi utama pembangunan berkelanjutan yaitu lingkungan, ekonomi, dan sosial; (2) Menentukan alternatif strategi kebijakan yang terbaik dalam penerapan green campus di Undip untuk terciptanya kampus Undip yang berkelanjutan; serta (3) Membuat perencanaan anggaran keberlanjutan kampus Undip. Metode analisis yang digunakan adalah analisis deskriptif kualitatif dan kuantitatif. Alat analisis yang digunakan adalah metode Analytical Hierarchy Process (AHP) dengan bantuan Expert Choice versi 11. Berdasarkan hasil analisis bahwa penerapan green campus di Undip sudah dilakukan dengan baik, tetapi belum diintegrasikan secara menyeluruh. Kebijakan-kebijakan yang dilakukan oleh Undip, secara keseluruhan belum dapat memberikan manfaat positif bagi lingkungan, ekonomi, dan sosial, sehingga kampus Undip belum dapat dikatakan sebagai kampus yang berkelanjutan.
\end{abstract}

Kata kunci: perencanaan; penganggaran; pembangunan berkelanjutan; green campus

\begin{abstract}
[Planning and Budgeting of Green Campus Diponegoro University] Green campus are system of education, research, and community service with environment-friendly and engaging the campus community in environmental activities that can provide positive benefits for the environment, economic, and social. The purpose of this study is: (1) analyze the application of a green campus in Undip based on three main dimensions of sustainable development, namely environmental, economic, and social; (2) Determine the best alternative policy strategies in the implementation of a green campus at Undip for the creation of a sustainable campus; and (3) Make a budget plan Undip campus sustainability. The analytical method used are descriptive qualitative and quantitative analysis. The analytical tool used is Analytical Hierarchy Process (AHP) with Expert Choice version 11. Based on the analysis that the implementation of green campus in Undip have done well, but has not been integrated thoroughly. Policies undertaken by Undip, have generally not been able to provide positive benefits for the environment, economy, and social, so Undip can not be said as a sustainable campus.
\end{abstract}

Keywords: planning; budgeting; sustainable development; green campus

\section{Pendahuluan}

Sebuah pembangunan berdimensi lingkungan hidup atau berwawasan lingkungan yang dikenal dengan istilah pembangunan berkelanjutan, telah disepakati sebagian besar negara di dunia termasuk Indonesia sebagai konsep, strategi, dan model yang diharapkan mampu menjaga pelestarian fungsi lingkungan (Hadi, 2005). Dalam menciptakan pembangunan kampus yang berkelanjutan, maka Universitas Diponegoro menerapkan green campus. Kegiatan yang dilakukan oleh Universitas dapat

\footnotetext{
${ }^{*}$ Penulis Korespondensi.

E-mail: irmadewihapsari@gmail.com
}

memberikan contoh kepada masyarakat akan pentingnya aktivitas lingkungan yang berkelanjutan. Lingkungan bersih, sehat, dan asri inilah yang disebut "Green Campus" dimana bertujuan tidak hanya mendukung pelayanan prima tetapi juga ikut berpartisipasi dan bertanggung jawab dalam menciptakan kampus yang berkelanjutan (Nasoetion, 2009). Universitas Diponegoro dipilih sebagai studi kasus dalam penelitian ini karena: (1) pada tahun 2013 Undip juga mengikuti lomba green campus yang diikuti oleh 360 Universitas di seluruh dunia dimana Undip memperoleh peringkat ke-47 dunia dan ke-3 di Indonesia; serta (2) untuk menjadikan Undip sebagai kampus yang berkelanjutan. 
Penelitian terdahulu yang dilakukan oleh Johan Iskandar (2004) dengan judul Green Campus: Pengelolaan Kampus Ramah Lingkungan (Studi Kasus: Universitas Padjajaran, Jatinangor) bertujuan untuk melihat pengelolaan kampus ramah lingkungan di Universitas Padjajaran dengan melihat pada contohcontoh pengelolaan kampus di negara maju. Penelitian ini menggunakan metode analisis deskriptif kualitatif. Dari hasil analisis diketahui bahwa lingkungan Universitas Padjajaran dapat dikelola secara berwawasan lingkungan dengan menerapkan prinsipprinsip ekologi. Hal itu dilakukan dengan membuat zonasi (tata ruang) yang serasi dan terintegrasi, dimana zonasi tersebut dirancang untuk kepentingan lingkungan, sosial ekonomi, dan budaya seluruh civitas akademika Unpad.

Penelitian kedua yaitu dilakukan oleh Ruby Phramesti (2013) dengan judul Keberlanjutan UNNES sebagai Kampus Konservasi (Studi Kasus: UNNES Sekaran, Semarang) bertujuan untuk mengkaji dan menilai upaya perwujudan pendekatan keberlanjutan dalam pembangunan serta melakukan pengembangan kampus konservasi. Penelitian tersebut menggunakan pendekatan kuantitatif dengan teknik analisis deskriptif kualitatif dan deskriptif kuantitatif. Alat analisis yang digunakan yaitu pembobotan/ skoring dengan metode Stugers untuk menentukan banyaknya interval kelas. Hasil penelitian ini adalah UNNES belum berkelanjutan karena masih terfokus pada satu pilar pembangunan berkelanjutan, yaitu lingkungan. Untuk aspek ekonomi dan sosial belum banyak dilakukan oleh UNNES dalam mendukung kampus berkelanjutan.

Menyadari pentingnya perencanaan kampus berkelanjutan Universitas Diponegoro, maka dibutuhkan adanya perencanaan anggaran. Sumber dana Undip diperoleh dari Rupiah Murni (RM), dana Penerimaan Negara Bukan Pajak (PNBP), dan pinjaman/ hibah luar negeri. Namun untuk anggaran keberlanjutan lingkungan diambilkan dari dana PNBP yang berasal dari UKT mahasiswa dan kerjasama dengan pemerintah maupun beberapa instansi. Menurut Sabeni dan Ghozali, anggaran pemerintah adalah jenis rencana yang menggambarkan rangkaian tindakan atau kegiatan yang dinyatakan dalam bentuk angka-angka rupiah untuk suatu jangka waktu tertentu. Sedangkan secara umum anggaran diartikan sebagai rencana keuangan yang mencerminkan pilihan kebijaksanaan untuk suatu periode di masa yang akan datang (Baswir, 1999). Sehingga anggaran tidak jauh berbeda dengan suatu rencana kegiatan.

Dalam perencanaan dan penganggaran kampus berkelanjutan ini, masih terdapat beberapa permasalahan yang dihadapi oleh Undip, yaitu (1) Kurangnya pemeliharaan ruang terbuka hijau dan hutan kampus; (2) Konsumsi listrik di Undip sangat tinggi, sehingga tidak menghemat konsumsi energi dan membutuhkan dana lebih untuk aktivitas kantor. Lebih dari $75 \%$ bangunan atau gedung yang ada di Undip masih menggunakan lampu untuk pencahayaan di siang hari. Misalnya di beberapa gedung Fakultas Teknik dan Fakultas Ekonomi; (3) Lebih dari 50\% tempat sampah di Undip belum dibedakan antara sampah organik dan sampah anorganik serta belum adanya pengelolaan limbah universitas secara terpadu; (4) Kualitas air bersih yang rendah, air berwarna keruh dan kadang bau; (5) Semakin banyak jumlah kendaraan pribadi yang masuk ke Undip sehingga mengakibatkan kemacetan pada jam-jam tertentu dan meningkatkan pencemaran udara; (6) Belum ada lembaga khusus yang menangani kondisi lingkungan Undip, seperti Ganesha Hijau ITB dan Green Community di UI; serta (7) Belum adanya anggaran yang secara khusus dialokasikan untuk keberlanjutan kampus Undip.

Oleh karena itu, perlu adanya penerapan green campus di Undip sehingga dapat mewujudkan kampus yang berkelanjutan dengan melihat pada 3 dimensi pembangunan berkelanjutan yaitu lingkungan, ekonomi, dan sosial; menentukan alternatif kebijakan yang terbaik dalam penerapan green campus dengan menggunakan Analytical Hierarchy Process (AHP), serta membuat perencanaan anggaran untuk keberlanjutan kampus Undip

Tujuan dari penelitian ini adalah menganalisis penerapan green campus di Undip berdasarkan tiga dimensi utama pembangunan berkelanjutan yaitu lingkungan, ekonomi, dan sosial; menentukan alternatif strategi kebijakan yang terbaik dalam penerapan green campus di Undip untuk terciptanya kampus Undip yang berkelanjutan, dan membuat perencanaan anggaran keberlanjutan kampus Undip. Penelitian ini diharapkan dapat bermanfaat bagi Universitas Diponegoro dalam menerapkan green campus berdasarkan tiga dimensi utama pembangunan berkelanjutan yaitu lingkungan, ekonomi, dan sosial. Kemanfaatan ekonomi yang dapat diperoleh adalah terwujudnya kampus ramah lingkungan yang berkelanjutan, dimana menjamin efisiensi penggunaan sumber daya dan energi di dalam kampus.

\section{Metode Penelitian}

Teknik pengambilan sampel dilakukan dengan Judgment Sampling yaitu pengambilan sampel berdasarkan pertimbangan tertentu. Responden dalam penelitian ini adalah pihak-pihak yang mempunyai kewenangan mengambil keputusan (decision makers) dalam hal penerapan green campus di Undip, yaitu pembuat kebijakan dalam hal penerapan green campus di Undip serta Dosen Undip sebagai pakar tata ruang, pakar lingkungan, dan pakar transportasi. Sedangkan tenaga kependidikan Undip dan mahasiswa dipilih sebagai sampel dengan pertimbangan bahwa mereka ikut menikmati lingkungan kampus Universitas Diponegoro. Jumlah sampel 25 orang dengan tiap-tiap responden sebagai berikut:
1. Pakar Tata Ruang
2. Pakar Lingkungan
: 2 orang
3. Pakar Transportasi
: 3 orang
4. Pembuat Kebijakan : 2 orang 
$\begin{array}{ll}\text { 5. Tenaga kependidikan } & : 5 \text { orang } \\ \text { 6. Mahasiswa } & : 10 \text { orang } \\ \text { Metode analisis yang digunakan dalam }\end{array}$ penelitian ini adalah analisis deskriptif, dengan pendekatan analisis data kualitatif dan kuantitatif. Pendekatan analisis data kualitatif digunakan untuk meninjau penerapan green campus di Undip berdasarkan tiga dimensi utama pembangunan berkelanjutan (lingkungan, ekonomi, dan sosial), serta untuk membuat perencanaan anggaran keberlanjutan kampus Undip. Sedangkan pendekatan analisis data kuantitatif digunakan untuk menentukan alternatif strategi kebijakan yang terbaik dalam penerapan green campus di Undip untuk terciptanya kampus Undip yang berkelanjutan. Alat analisis yang digunakan adalah metode AHP (Analytical Hierarchy Process) dengan software program Expert Choice versi 11.

\section{Hasil dan Pembahasan}

Berikut analisis penerapan green campus di Undip, analisis penentuan prioritas strategi kebijakan dalam penerapan green campus di Undip, serta perencanaan anggaran keberlanjutan kampus Undip.

\subsection{Analisis Penerapan Green Campus di Undip}

Dalam mendukung penerapan green campus, Undip melakukan beberapa program kegiatan yang berkaitan dengan lingkungan dan pendidikan dengan tujuan untuk mengembangkan kampus yang selaras dengan lingkungan alam, yang berakar pada tradisi dan budaya bangsa sehingga dapat menumbuhkan kebijaksanaan yang dinamis.

Berikut analisis penerapan green campus di Undip menuju kampus yang berkelanjutan:

1. Tata letak dan infrastruktur

Apabila dilihat dari data dimana luas lahan terbangun Undip $230.000 \mathrm{~m}^{2}$ (10\% dari luas total Undip) dan luas ruang terbuka hijau $1.150 .000 \mathrm{~m}^{2}$ (50\% dari luas total Undip), maka perimbangan antara luas bangunan dengan ruang terbuka hijau di kampus Undip sudah ideal. Pembangunan gedung kuliah atau infrastruktur masih bisa dilakukan, karena total luas lahan terbangun yang diperbolehkan adalah $70 \%$ dari total luas keseluruhan kampus, sedangkan luas terbangun Undip masih 10\%-nya. Pengelolaan taman kampus Undip dilakukan dengan baik, sehingga dapat bermanfaat dalam mendaur ulang gas-gas $\mathrm{CO}_{2}$ di udara, sekaligus menghasilkan udara segar $\left(\mathrm{O}_{2}\right)$ yang memberikan kenyamanan bagi lingkungan sekitarnya, yang berarti juga akan mengurangi pemanasan global. Disamping itu, dengan adanya vegetasi/tanaman dapat memberikan nilai estetika/keindahan tersendiri bagi lingkungan kampus Undip.

\section{Energi dan Perubahan Iklim}

Saat ini Undip sedang mengimplementasikan kebijakan dan program untuk pengurangan emisi gas rumah kaca dan perubahan iklim, salah satunya diwujudkan dalam bentuk penanaman pohon yang secara rutin dilakukan setiap hari Jumat setelah kegiatan bersepeda dan senam bersama. Penerapan green campus di Undip yang berkaitan dengan energi dan perubahan iklim dapat dilihat dari penggunaan energi terbarukan berupa biogas, energi surya, dan mikrohidro. Namun penggunaan energi terbarukan tersebut hanya sebagian kecil saja. Misalnya: penggunaan biogas di Teknik Kimia yang dimanfaatkan untuk operasional kantin serta pemasangan lampu jalan yang menggunakan energi surya di sepanjang koridor pintu masuk gerbang Undip. Kurangnya kesadaran civitas akademik serta kurangnya peralatan untuk mendukung program energi terbarukan, menjadikan kampus Undip belum secara menyeluruh dalam menerapkan program tersebut.

\section{Sampah}

Pembuangan sampah di Undip sudah ada yang dibedakan antara sampah organik dan non-organik, tetapi hal tersebut belum dilakukan menyeluruh di kampus Undip, hanya beberapa jurusan saja yang telah memilah sampah dengan baik. Pembuangan sampah saat ini masih dikumpulkan di belakang rusunawa Undip. Undip belum memiliki pembuangan sampah yang juga disertai dengan alat untuk mengolah sampah-sampah tersebut. Namun, rencana ke depan, Undip akan bekerjasama dengan Pemkot Kudus dalam hal pengolahan limbah Universitas. Diharapkan nantinya, sampah-sampah yang dihasilkan oleh Undip dapat menjadi kompos yang dapat digunakan untuk taman-taman kampus. Secara keseluruhan, kampus Undip termasuk kampus yang bersih dan nyaman. Meskipun pembuangan sampah banyak yang tidak dibedakan antara sampah organik dan anorganik, namun kesadaran masyarakat kampus dalam hal pembuangan sampah cukup tinggi dengan tidak membuang sampah sembarang tempat, sehingga pencemaran tanah akan sampah semakin berkurang.

4. Air

Kampus Undip telah melakukan program konservasi air berupa biopori dan sumur resapan, seperti yang telah dilakukan oleh Fakultas Perikanan dan Ilmu Kelautan, yaitu dengan cara membuat penampungan air hujan agar air hujan tidak sia-sia mengalir sebagai air permukaan dan terbuang ke laut. Air hujan tersebut selanjutnya dapat mengisi air tanah, kemudian tersimpan sebagai air persediaan pada saat musim kemarau. Namun keberadaan biopori di kampus Undip tidak sebanding dengan luas total wilayah Undip, sehingga perlu adanya sosialisasi kepada seluruh fakultas agar membuat biopori di masing-masing unit kerja. Semakin banyak biopori, maka semakin tinggi daya resapan air dan semakin meningkat volume air tanah di kampus Undip. Selain biopori, 
Undip juga bekerjasama dengan Kementerian Pekerjaan Umum dengan membuat bendungan/ waduk di kawasan Undip yang dimanfaatkan untuk sumber air bersih, untuk menaikkan air tanah, pembangkit mini hidro, serta sebagai laboratorium bagi Fakultas Perikanan dan Ilmu Kelautan.

\section{Transportasi}

Dalam hal transportasi, melihat dari jumlah mobil pribadi yang memasuki wilayah Undip rata-rata 350 mobil/ hari sehingga mengakibatkan kemacetan di saat peak hour, maka Undip membuat beberapa kebijakan, diantaranya: kebijakan berupa car free day yang diadakan tiap 1 bulan sekali pada hari Jumat setiap pukul 06.00 09.00 dimana semua jenis kendaraan dilarang memasuki kawasan Undip. Hal itu bermanfaat bagi lingkungan Undip, setidaknya pencemaran yang dihasilkan oleh kendaraan pribadi berkurang. Selain itu, Undip juga telah menyediakan bus sebagai sarana transportasi massal bagi pegawai Undip pada saat jam datang dan pulang kerja. Namun bus yang disediakan hanya satu, alangkah lebih baik lagi jika Undip mampu menambah jumlah bus sehingga rute bus untuk antar jemput pegawai akan lebih merata lagi (tidak hanya rute Undip Pleburan - Undip Tembalang). Selain itu, Undip juga dapat menyediakan bus untuk operasional di dalam kampus, sehingga mahasiswa, dosen, dan staf Undip dapat menggunakan Bus sebagai alat transportasi di dalam kampus. Undip juga telah menyediakan jalur khusus untuk sepeda dan tempat parkir khusus untuk sepeda. Namun, hal itu kurang dimanfaatkan oleh civitas akademika, sehingga banyak tempat parkir sepeda yang kosong. Menurut para responden, penggunaan sepeda sebagai alat transportasi di Undip kurang diminati, karena kontur Undip yang tidak rata membuat pengendara sepeda harus bekerja keras untuk sampai ke tempat kerja.

\section{Pendidikan}

Dalam bidang pendidikan, Undip telah mengadakan sejumlah penelitian tentang lingkungan, mengadakan seminar nasional maupun internasional tentang penataan lingkungan, membuat wadah/ jurnal untuk publikasi ilmiah, serta membuat website tentang green campus. Namun kegiatan tersebut kurang menjamin adanya peningkatan kualitas lingkungan di Undip. Untuk itu, perlu adanya peningkatan sarana dan prasarana (fasilitas fisik) penunjang hal-hal yang berkaitan dengan ramah lingkungan (green infrastructure), misalnya membuat green spot yaitu sebuah tempat sebagai tempat sumber informasi dan edukasi mengenai permasalahan lingkungan (seperti halnya di ITB), serta membuat kebijakan atau peraturan rektorat dalam penegasan hal-hal yang berkaitan dengan kepedulian terhadap lingkungan hidup.

\subsection{Analisis Penentuan Prioritas Strategi Kebijakan dalam Penerapan Green Campus di Universitas Diponegoro}

Penelitian ini menggunakan 25 responden. Hasil analisis penentuan prioritas strategi kebijakan dalam penerapan green campus di Universitas Diponegoro dilakukan dengan menggunakan metode Analytical Hierarchy Process (AHP) dengan bantuan software expert choice 11. Metode AHP dilakukan dengan teknik perbandingan berpasangan antara beberapa kriteria yang menjadi prioritas melalui sebuah matriks yang dinamakan matriks pair-wise. Adapun kriteria dan prioritas kebijakan yang diperbandingkan, dapat dilihat pada Gambar 1, Tabel $1-7$.

Pada Gambar 1 tersebut, dapat dijelaskan sebagai berikut:

(a). Ditinjau dari aspek tata letak dan infrastruktur

A1. Memperluas daerah ruang terbuka hijau

A2. Memperluas daerah non-retentif

A3. Menerapkan anggaran keberlanjutan penataan lingkungan kampus

(b) Ditinjau dari aspek energi dan perubahan iklim

B1. Menggunakan peralatan hemat energi

B2. Menggunakan energi terbarukan

B3. Menerapkan program konservasi energi

B4. Menerapkan konsep green building

B5. Menerapkan mitigasi perubahan iklim

B6. Mengurangi emisi gas rumah kaca

(c) Ditinjau dari aspek sampah

C1. Menerapkan program daur ulang untuk limbah universitas

C2. Mengurangi penggunaan kertas dan plastik di kampus

(d) Ditinjau dari aspek air

D1. Menerapkan program konservasi air

D2. Penggunaan pipa air/ piped water

(e) Ditinjau dari aspek transportasi

E1. Membatasi kendaraan pribadi yang masuk kampus

E2. Membatasi ruang parkir kendaraan pribadi

E3. Menyediakan sarana bus kampus untuk staf dan mahasiswa

E4. Pembangunan jalur pejalan kaki dan sepeda

(f) Ditinjau dari aspek pendidikan

F1. Membuat kurikulum tentang keberlanjutan kampus

F2. Mengalokasikan dana penelitian untuk penataan lingkungan kampus

F3. Menyediakan wadah/ jurnal untuk publikasi ilmiah mengenai penataan lingkungan kampus

F4. Mengadakan seminar nasional tentang penataan lingkungan kampus

F5. Menggalakkan organisasi kemahasiswaan yang berhubungan dengan lingkungan dan kelembagaan di Universitas Diponegoro yang menangani masalah penataan lingkungan kampus.

F6. Menyediakan website universitas yang memberikan informasi rinci tentang penataan lingkungan kampus. 


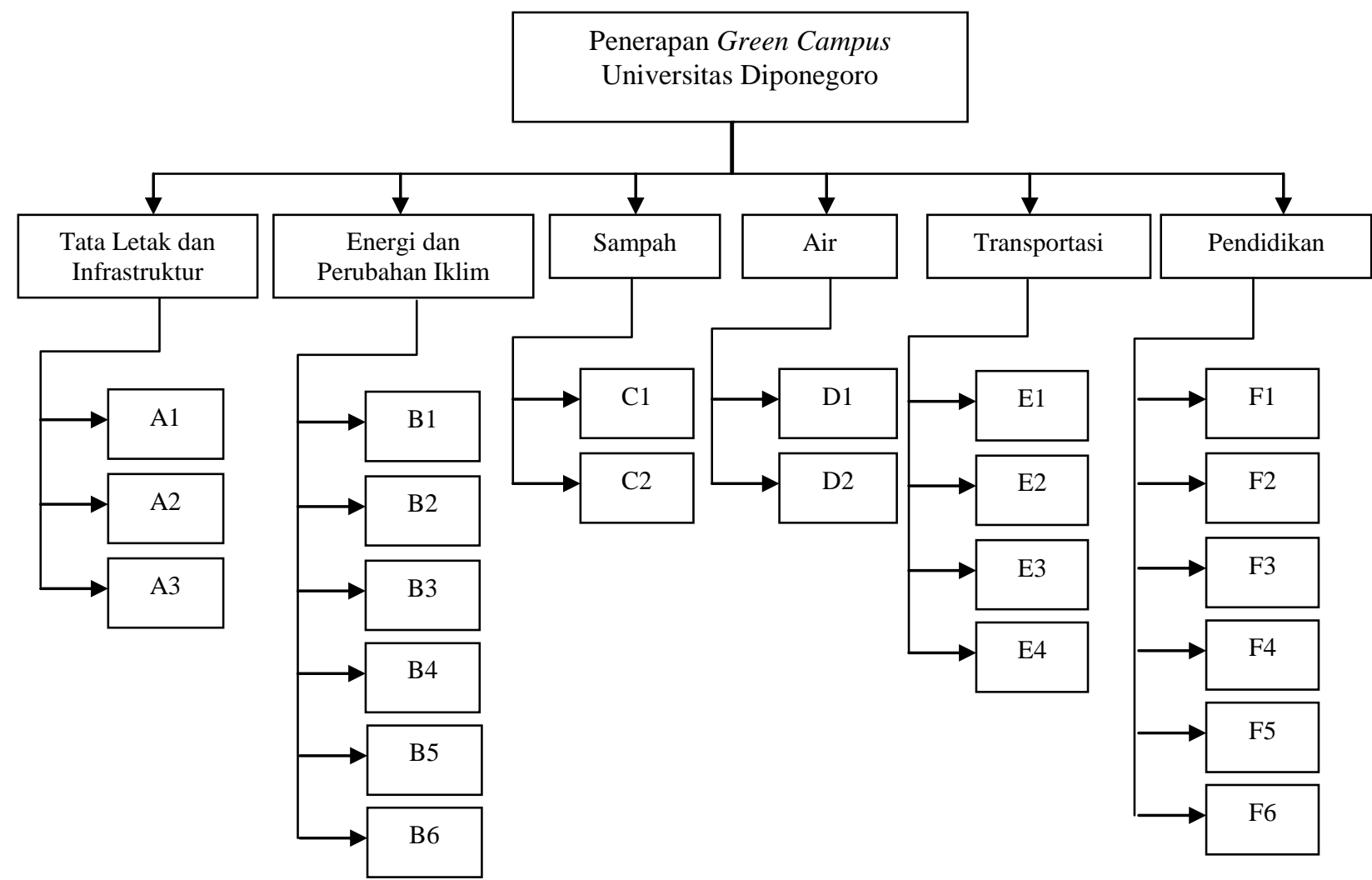

Gambar 1. Skema hierarki AHP dalam rangka menentukan alternatif strategi kebijakan yang terbaik dalam penerapan Green Campus di Undip untuk terciptanya kampus undip yang berkelanjutan

Tabel 1. Bobot final kriteria strategi kebijakan dalam penerapan Green Campus di Universitas Diponegoro

\begin{tabular}{lcc}
\hline $\begin{array}{l}\text { Kriteria Strategi Kebijakan } \\
\text { Penerapan Green Campus }\end{array}$ & $\begin{array}{c}\text { Bobot } \\
\text { Final } \\
(\%)\end{array}$ & Ranking \\
\hline Air & 19,8 & 1 \\
Transportasi & 19,5 & 2 \\
Tata letak dan infrastruktur & 17,2 & 3 \\
Pendidikan & 16,0 & 4 \\
Sampah & 14,7 & 5 \\
Energi dan perubahan iklim & 12,7 & 6 \\
\hline
\end{tabular}

Tabel 2. Prioritas kebijakan pada kriteria tata letak dan infrastruktur

\begin{tabular}{lc}
\hline $\begin{array}{c}\text { Kriteria Prioritas Kebijakan Penerapan } \\
\text { Green Campus }\end{array}$ & $\begin{array}{c}\text { Bobot } \\
\text { Final } \\
(\%)\end{array}$ \\
\hline Memperluas daerah ruang terbuka hijau & 28,9 \\
Memperluas daerah non retentif & 12,1 \\
Menerapkan anggaran keberlanjutan & 59,0 \\
penataan lingkungan kampus & \\
\hline
\end{tabular}

Tabel 3. Prioritas kebijakan pada kriteria energi dan perubahan iklim

\begin{tabular}{lc}
\hline $\begin{array}{c}\text { Kriteria Prioritas Kebijakan Penerapan } \\
\text { Green Campus }\end{array}$ & $\begin{array}{c}\text { Bobot } \\
\text { Final } \\
(\%)\end{array}$ \\
\hline Menggunakan peralatan hemat energi & 15,3 \\
Menggunakan energi terbarukan & 10,9 \\
Menerapkan program konservasi energi & 14,3 \\
Menerapkan konsep green building & 31,3 \\
Menerapkan mitigasi perubahan iklim & 12,5 \\
Mengurangi emisi gas rumah kaca & 15,6 \\
\hline
\end{tabular}

Tabel 4. Prioritas kebijakan pada kriteria sampah

\begin{tabular}{lc}
\hline $\begin{array}{c}\text { Kriteria Prioritas Kebijakan Penerapan } \\
\text { Green Campus }\end{array}$ & $\begin{array}{c}\text { Bobot } \\
\text { Final } \\
(\%)\end{array}$ \\
\hline $\begin{array}{l}\text { Menerapkan program daur ulang untuk } \\
\text { limbah universitas }\end{array}$ & 50,1 \\
$\begin{array}{l}\text { Mengurangi penggunaan plastik dan } \\
\text { kertas di kampus }\end{array}$ & 49,9 \\
\hline
\end{tabular}


Tabel 5. Prioritas kebijakan pada kriteria air

\begin{tabular}{lc}
\hline $\begin{array}{l}\text { Kriteria Prioritas Kebijakan Penerapan } \\
\text { Green Campus }\end{array}$ & $\begin{array}{c}\text { Bobot Final } \\
(\%)\end{array}$ \\
\hline $\begin{array}{l}\text { Menerapkan program konservasi air } \\
\text { Penggunaan pipa air/ piped water }\end{array}$ & 68,3 \\
\hline
\end{tabular}

Tabel 6. Prioritas kebijakan pada kriteria transportasi

\begin{tabular}{lc}
\hline $\begin{array}{l}\text { Kriteria Prioritas Kebijakan Penerapan } \\
\text { Green Campus }\end{array}$ & $\begin{array}{c}\text { Bobot Final } \\
(\%)\end{array}$ \\
\hline $\begin{array}{l}\text { Membatasi kendaraan pribadi yang } \\
\text { masuk kampus }\end{array}$ & 16,6 \\
$\begin{array}{l}\text { Membatasi ruang parkir kendaraan } \\
\text { pribadi }\end{array}$ & 10,1 \\
$\begin{array}{l}\text { Menyediakan sarana bus kampus } \\
\text { untuk staf dan mahasiswa }\end{array}$ & 55,5 \\
$\begin{array}{l}\text { Pembangungan jalur pejalan kaki dan } \\
\text { sepeda }\end{array}$ & 17,9 \\
\hline
\end{tabular}

Tabel 7. Prioritas kebijakan pada kriteria pendidikan

\begin{tabular}{lr}
\hline $\begin{array}{l}\text { Kriteria Prioritas Kebijakan Penerapan } \\
\text { Green Campus }\end{array}$ & $\begin{array}{c}\text { Bobot } \\
\text { Final } \\
(\%)\end{array}$ \\
\hline $\begin{array}{l}\text { Membuat kurikulum keberlanjutan } \\
\text { kampus }\end{array}$ & 13,4 \\
$\begin{array}{l}\text { Mengalokasikan dana penelitian u lingk } \\
\text { Menyediakan wadah/ jurnal u publikasi }\end{array}$ & 13,9 \\
$\begin{array}{l}\text { ilmiah tentang penataan lingkungan } \\
\text { Mengadakan seminar nasional }\end{array}$ & 9,9 \\
$\begin{array}{l}\text { Menggalakkan organisasi } \\
\text { kemahasiswaan }\end{array}$ & 32,4 \\
Menyediakan website universitas & 21,0 \\
\hline
\end{tabular}

\subsection{Perencanaan Anggaran Keberlanjutan Kampus Undip Tembalang}

Total anggaran Undip pada tahun 2013 dari Penerimaan Negara Bukan Pajak (PNBP) adalah sebesar Rp. 393.547.436.000,- dan Rupiah Murni (RM) sebesar Rp. 369.474.938.000,-. Sedangkan total anggaran Undip pada tahun 2014 dari PNBP adalah sebesar Rp. 366.790.108.000,- dan dari RM sebesar Rp. $\quad 369.474 .938 .000,-$. Berdasarkan data UI greenmetric world university ranking 2013, bahwa anggaran Undip yang digunakan untuk kegiatan yang terkait dengan green campus menuju pembangunan berkelanjutan adalah $\pm 10 \%$ dari total anggaran Undip yang berasal dari Penerimaan Negara Bukan Pajak (PNBP). Padahal berdasarkan kenyataan yang ada, Undip belum memiliki perencanaan anggaran yang khusus untuk kegiatan green campus atau lingkungan kampus dalam mencapai kampus yang berkelanjutan. Oleh karena itu, peneliti mencoba membuat perencanaan anggaran untuk keberlanjutan kampus
Undip yang akan direncanakan untuk tahun 20152019.

Perencanaan anggaran tersebut disesuaikan dengan Peraturan Menteri Keuangan Republik Indonesia No.53/PMK.02/2014 tentang Standar Biaya Masukan Tahun Anggaran 2015, Keputusan Rektor Universitas Diponegoro No.473/UN7.P/HK/2014 tentang Standar Biaya Daftar Isian Pelaksanaan Anggaran (DIPA) Sumber Dana Penerimaan Negara Bukan Pajak (PNBP) Universitas Diponegoro Tahun Anggaran 2014, Peraturan Menteri Pekerjaan Umum Republik Indonesia No.03/PRT/M/2013 tentang Penyelenggaraan Sarana dan Prasarana Persampahan Dalam Penanganan Sampah Rumah Tangga dan Sampah Sejenis Sampah Rumah Tangga, serta Peraturan Gubernur Jawa Tengah No.33 Tahun 2013 tentang Standardisasi Kegiatan dan Honorarium Biaya Pemeliharaan dan Standardisasi Harga Pengadaan Barang/ Jasa Kebutuhan Pemerintah Provinsi Jawa Tengah Tahun 2014.

Program dan kegiatan yang akan dilakukan oleh Undip untuk mendukung green campus/ keberlanjutan kampus disesuaikan dengan permasalahan yang ada, yaitu sebagai berikut:

1. Penghijauan daerah tangkapan air

Tujuan pemeliharaan daerah tangkapan air tersebut adalah untuk menjaga kelestarian lingkungan kampus dan meningkatkan daya serap daerah tangkapan air yang dapat menambah jumlah air tanah dan mencegah terjadinya banjir.

2. Pemeliharaan taman kampus dan hutan kampus Pemeliharaan taman kampus dilakukan untuk menjaga kelestarian lingkungan kampus Undip dan meningkatkan kadar oksigen yang dihasilkan oleh tanaman. Selain itu, keberadaan taman dan hutan kampus dapat digunakan untuk menambah nilai estika Undip.

3. Penyuluhan/ seminar tentang pemanasan global Penyuluhan terkait dengan pemanasan global dilakukan kepada masyarakat kampus untuk meningkatkan pengetahuan mereka tentang energi dan perubahan iklim. Estimasi jumlah peserta 750 orang/ kegiatan dan dilaksanakan di Gd. Prof. Sudharto, Undip.

4. Menerapkan konsep green building

Konsep green building dilakukan dengan cara merenovasi bangunan yang ada agar menjadi bangunan yang ramah lingkungan. Renovasi dilakukan pada seluruh bangunan di Universitas Diponegoro, baik bangunan bertingkat maupun bangunan tidak bertingkat yang belum memenuhi standar bangunan green building. Berdasarkan data UI greenmetric world university ranking 2013, total luas area terbangun di Undip adalah $230.000 \mathrm{~m}^{2}$ yang $80 \%$ berupa bangunan bertingkat yaitu sebesar $184.000 \mathrm{~m}^{2}$ dan $20 \%$ bangunan tidak bertingkat yaitu sebesar 46.000 $\mathrm{m}^{2}$. Renovasi ini dilaksanakan selama 5 tahun, dimulai pada tahun 2015 hingga 2019. 
5. Penerapan energi terbarukan

Penerapan energi terbarukan dilakukan dengan memanfaatkan energi biogas untuk kantin di masing-masing jurusan/ program studi di lingkungan Undip. Sedangkan lampu energi surya dipasang di sepanjang koridor jalan utama Undip. Jumlah fakultas di Undip adalah 11 fakultas dan program pasca sarjana. Jumlah kantin di Undip yang direncanakan menggunakan energi alternatif biogas adalah 2 kantin tiap fakultas, sehingga $2 \times 22=24$ kantin. Lampu energi surya yang dibutuhkan sejumlah 100 lampu. Biogas adalah gas yang merupakan produk akhir pencernaan anaerobik biomassa oleh mikro organisme di dalam tangki pencerna (digester) dengan komponen utama metana 40\% (empat puluh persen) sampai dengan 70\% (tujuh puluh persen) dan karbondioksida. Peralatan yang dibutuhkan untuk pembuatan biogas adalah sebagai berikut:

a. Tangki pencerna (digesteli, dengan bak dan saluran pemasukan bahan baku maupun bak dan saluran pengeluaran bahan organik;

b. Penyaluran biogas terdiri atas pemipaan, penguras air (water drain), keran gas, dan manometer;

c. Kompor terdiri atas kompor biogas dan pemantik api;

6. Penyediaan sarana dan prasarana pengelolaan persampahan

Tujuan dari penyediaan sarana persampahan yaitu tersedianya tempat sampah organik dan anorganik, sehingga memudahkan untuk memilah sampah yang dapat dilakukan daur ulang, serta untuk mengurangi timbunan sampah. Untuk lokasi tertentu, seperti di Rektorat dan koridor jalan kampus Undip sudah tersedia tempat sampah yang dibedakan, namun untuk masingmasing jurusan/ program studi belum tersedia tempat sampah tersebut. Jumlah jurusan/ program studi di Undip mencapai 110 jurusan. Tahun 2015 akan direncanakan pembelian 220 set tempat sampah, sehingga masing-masing jurusan/ program studi mendapat 2 set tempat sampah.

7. Pembuatan TPS terpadu untuk pembuangan sampah dan pengolahan limbah terpadu

Pembuatan TPS terpadu akan dilaksanakan pada tahun 2015 dengan jangka waktu 2 tahun.

8. Pembuatan biopori

Pembuatan biopori ini bermanfaat untuk meningkatkan daya resapan air dan kualitas air tanah. Jumlah biopori yang dibuat adalah 110 unit sesuai dengan jumlah jurusan/ program studi.

9. Pembuatan sumur buatan

Pembuatan sumur buatan sebanyak 12 sumur disesuaikan dengan jumlah fakultas/ program studi di Undip.

10. Program car free day

Program car free day dilaksanakan tiap hari Jumat. Tujuan dari pelaksanaan kegiatan ini adalah untuk mengurangi penggunaan kendaraan pribadi walau hanya 3 jam. Dengan adanya car free day dapat mengurangi jumlah pencemaran udara di lingkungan kampus Undip. Pelaksanaan kegiatan ini tidak mengeluarkan biaya.

11. Pemeliharaan rutin/ berkala kendaraan dinas Pemeliharaan rutin kendaraan dinas bertujuan untuk menjaga kualitas kendaraan dinas yang dimiliki oleh Undip.

12. Pengadaan bus kampus Undip

Pengadaan bus kampus bertujuan sebagai alat transportasi di dalam lingkungan kampus, sehingga dapat mengurangi pencemaran udara di lingkungan kampus. Masyarakat kampus yang membawa kendaraan pribadi diwajibkan untuk meninggalkan kendaraan tersebut di tempat parkir yang telah disediakan oleh Undip. Jumlah pengadaan bus kampus sebanyak 2 unit.

13. Pembuatan green spot

Green spot sebuah tempat sebagai sumber informasi dan edukasi mengenai permasalahan lingkungan. Green spot ini memanfaatkan bangunan PKM (Pusat Kegiatan Mahasiswa) yang telah dibangun oleh Undip di sebelah Koperasi, sehingga tidak diperlukan biaya untuk pembangunan green spot.

\section{Kesimpulan}

Berdasarkan UI Greenmetric World University Ranking 2013, ukuran keberhasilan green campus adalah: tata letak dan infrastruktur, energi dan perubahan iklim, sampah, air, transportasi, dan pendidikan. Penerapan green campus di Undip sudah dilakukan dengan baik, tetapi belum diintegrasikan secara menyeluruh. Kebijakan-kebijakan yang dilakukan oleh Undip secara keseluruhan belum dapat memberikan manfaat positif bagi lingkungan, ekonomi, dan sosial, sehingga kampus Undip belum dapat dikatakan sebagai kampus yang berkelanjutan (sustainable campus).

Dalam mewujudkan kampus berkelanjutan, dilakukan beberapa alternatif kebijakan yang diperoleh melalui analisis AHP, yaitu: (1) Menerapkan angaran keberlanjutan penataan lingkungan kampus, (2) Menerapkan konsep green building, (3) Menerapkan program daur ulang untuk limbah universitas, (4) Menerapkan program konservasi air, (5) Menyediakan sarana bus kampus untuk staf dan mahasiswa, serta (6) Menggalakkan organisasi kemahasiswaan yang berhubungan dengan lingkungan dan kelembagaan di Universitas Diponegoro yang menangani masalah penataan lingkungan kampus. Untuk mewujudkan kebijakan green campus tersebut dalam suatu program dan kegiatan, maka dibutuhkan perencanaan anggaran green campus Undip. 


\section{Daftar Pustaka}

Baswir, Revrisond. (1999). Akutansi Pemerintah Indonesia. Yogjakarta: BPFE.

Guidelines of UI Greenmetric World University Ranking 2013. Available Online at: greenmetric@ui.ac.id.

Hadi, S.P. 2005. Dimensi Lingkungan Perencanaan Pembangunan. Cetakan Kedua. Yogyakarta: Gadjah Mada University Press.

Iskandar, Johan. (2004). Green Campus: Pengelolaan Kampus Ramah Lingkungan, Jurnal Biotika. Vol.3(1), 10-15.

Keputusan Rektor Universitas Diponegoro No.473/UN7.P/HK/2014 tentang Standar Biaya Daftar Isian Pelaksanaan Anggaran (DIPA) Sumber Dana Penerimaan Negara Bukan Pajak (PNBP) Universitas Diponegoro Tahun Anggaran 2014.

Nasoetion, P. 2009. Green Campus Vs. Pemanasan Global. Jaringan Hijau mandiri. Available Online at: http://www.gogreenindonesiaku. $\mathrm{com} /$ green_opinion2.php.
Peraturan Gubernur Jawa Tengah No.33 Tahun 2013 tentang Standardisasi Kegiatan dan Honorarium Biaya Pemeliharaan dan Standardisasi Harga Pengadaan Barang/ Jasa Kebutuhan Pemerintah Provinsi Jawa Tengah Tahun 2014

Peraturan Menteri Keuangan Republik Indonesia No.53/PMK.02/2014 tentang Standar Biaya Masukan Tahun Anggaran 2015.

Peraturan Menteri Pekerjaan Umum Republik Indonesia No.03/PRT/M/2013 tentang Penyelenggaraan Sarana dan Prasarana Persampahan Dalam Penanganan Sampah Rumah Tangga dan Sampah Sejenis Sampah Rumah Tangga.

Saaty, Thomas L. 1991. Pengambilan Keputusan Bagi Para Pemimpin. Terjemahan. Cetakan Pertama, Jakarta: PT. Pustaka Binaman Pressindo. 